\title{
REALITY OR ILLUSION? THE EFFICACY OF NONMARKET STRATEGY IN INSTITUTIONAL RISK REDUCTION
}

\begin{abstract}
Nonmarket strategy researchers have postulated that political and social strategies reduce the exposure of firms to risk, but those arguments have received little empirical attention. In this paper, we integrate social capital and institutional theories to examine the efficacy of managerial political ties (MPT) and corporate social responsibility (CSR) in institutional risk reduction. Using survey data from 179 firms in Ghana, we find that whereas CSR reduces institutional risk exposure, MPT do not. We also find that the effect of MPT on risk exposure is moderated by public affairs functions. Contrary to extant literature, we do not find evidence of complementarity between MPT and CSR. Altogether, the findings do not only show that the proposed efficacy of MPT in risk reduction is illusive, but they also signal the need for scrutinizing the harmony between nonmarket political and social strategies.
\end{abstract}

\section{Keywords:}

Managerial political ties, corporate social responsibility, institutional risk exposure, emerging countries 


\section{Introduction}

There is growing research on the link between nonmarket strategy and organizational outcomes. Nonmarket strategy, which is defined as “a firm's concerted pattern of actions to improve its performance by managing the institutional or societal context of economic competition" (Mellahi et al., 2016: 143), has two key components: corporate political activity (CPA) and corporate social responsibility (CSR). Nonmarket scholars suggest that advancing our understanding of the link between nonmarket strategy and organizational outcomes requires the integration of both CPA and CSR (Hond, et al., 2014; Liedong et al., 2015; Darendeli and Hill, 2015). However, the combinative impact of engagement in CPA and CSR has not been examined to any great extent.

Though recent studies have shown the importance of integrating nonmarket social and political strategies (Mellahi et al., 2016), many of these studies are conceptual (e.g. Hond et al., 2014; Rehbein and Schuler, 2015). The few that are empirical have focused on developed countries (e.g. Hadani and Coombes, 2015; Werner, 2015). Building on Puck, Rogers, and Mohr (2013), Liedong et al., (2015) and Mellahi et al., (2016), we expand integrated nonmarket strategy research to emerging countries by addressing the following research questions: (1) what is the impact of managerial political ties (MPT) and CSR on institutional risk exposure; and (2) do Public Affairs (PA) functions help to reduce institutional risk exposure? Our study examines the singular and combined effects of MPT and CSR on institutional risk exposure, as well as the moderating effect of PA functions on MPT and CSR in Ghana ${ }^{1}$.

\footnotetext{
${ }^{1}$ Based on previous research (Peng \& Luo, 2000; White, Boddewyn, \& Galang, 2015), we define managerial political ties as the extent to which firms' managers establish and maintain informal relationships via personal networks with government officials, and CSR as corporate actions that improve social welfare (McWilliams \& Siegel, 2001; McWilliams, Siegel \& Wright, 2006). We also define institutional risk exposure as the sum of investment climate constraints resulting from weak market supporting institutions. This risk is more prevalent in emerging countries where political, economic and legal institutions are insufficiently developed (Schwens, Eiche, \& Kabst, 2011).
} 
We draw upon and integrate social capital theory and institutional theory to achieve our goal. Precisely, we rely on the micro-macro link of social capital theory (Peng and Luo, 2000; Acquaah, 2007) to argue that in emerging countries where market institutions are weak, the micro ties senior managers establish with influential politicians can enable their organizations to gain access to private information, influence government policy, and reduce exposure to institutional risk (Acquaah, 2007; Luo, 2001; Luo and Zhao, 2013; Peng and Luo, 2000). This argument is based on the new institutional economics perspective (North, 1990; Williamson, 2000) which emphasizes the effect of political governance on institutional structures (Doh, Lawton and Rajwani, 2012) and the strong link between political or regulatory uncertainty and nonmarket strategy (Kingsley, Vanden Bergh, and Bonardi, 2012; White et al., 2015). It is strengthened by the fact that political stakeholder management in emerging countries revolves around social ties and networks (Dieleman and Sachs, 2008; Rajwani and Liedong, 2015).

With respect to CSR and PA functions, we draw upon the legitimacy-based logic of institutional theory to argue that corporate responsibility and community initiatives enhance corporate reputation (Hond et al., 2014), strengthen trust between firms and institutional actors (Liedong et al., 2015) and confer legitimacy on firms (Park, Lee and Kim, 2014; Beddewela and Fairbrass, 2016). Legitimacy, which is about the adaptation of nonmarket initiatives to suit local institutional contexts (Mellahi et al., 2016), is particularly more important in emerging countries (Guo, Xu, and Jacobs, 2014) where weak institutional conditions put pressure on firms to ensure that their actions are desirable or appropriate within systems of norms and values established by institutional actors (Suchman, 1995; Zheng, Luo, and Maksimov, 2015). Similarly, weak institutional conditions in emerging countries make structural management of external affairs crucial (Greening and Gray, 1994), hence the need for PA functions. These functions are important links between firms and their 
external environments (Griffin and Dunn, 2004), and they are useful for managing institutional stakeholders who are reportedly the source of legitimacy (Chiu and Sharfman, 2011). We posit that legitimacy can lead to desirable organizational outcomes such as regulatory leniency (Hong and Liskovich, 2015) and risk reduction (Bansal and Roth, 2000; Luo, 2001; Henisz and Zelner, 2005; Stevens, Xie and Peng, 2016). Indeed, the results of this study show that CSR and PA functions significantly reduce risk exposure. However and contrary to expectations, the results also show that the main effect of MPT and the combined effect of MPT and CSR are insignificant.

Our study contributes to nonmarket strategy literature in three ways. First, it sheds light on the interactive effect of MPT and CSR and thus addresses the paucity of empirical research on integrated nonmarket strategy. It is worth noting that MPT and CSR have been studied, but in silos, and hence little is known about their combined effect on organizational outcomes (Mellahi et al., 2016; Lin et al., 2015; Sun, Mellahi and Wright, 2012; Frynas and Stephens, 2015).

Second, in addition to addressing the lack of research on the combinative effects of nonmarket initiatives, this study examines the role of PA - a function that supports CSR and MPT - but has largely been overlooked in extant studies. PA, CPA and CSR are different, but their difference is rarely articulated in nonmarket strategy research. We note that risk reduction requires firms to structurally manage their relationships with institutional actors (Kotter, 1979). However, organizational structures which support firms' political activities or strengthen legitimacy-building CSR initiatives have received little attention in nonmarket strategy research (Dieleman and Boddewyn, 2012), a shortcoming addressed in this study.

Third, this study examines an immediate outcome of nonmarket strategy institutional risk exposure - and thus departs from the trajectory of studying outcomes that are 
difficult to attribute to nonmarket strategies. Reviews of the literature reveal that the performance outcomes that are often investigated are distant from the direct influence of MPT or CSR, and this distance perhaps underlies the limited ability of nonmarket researchers to provide plausible explanations for the causal mechanisms of their findings (Puck et al., 2013), as the linkages may be improbable or unconvincing. Consequently, the lack of credible treatise of mediation curtails a deeper understanding of nonmarket strategy (Guo et al., 2014; Rajwani and Liedong, 2015). Our focus on institutional risk is both interesting and important because of the negative effect of institutional voids on firm survival and performance in emerging countries, especially in Africa. One of the greatest challenges for private sector development in Africa stems from disabling investment climates and nonsupporting institutional infrastructure. Firms on this continent are exposed to voids manifested by high levels of corruption and weak market supporting institutions which increase the cost of doing business (Khanna, Palepu, and Sinha, 2005; Acquaah, 2007; Puck et al., 2013). Set in the weak institutional environment of Ghana, this study examines a context-relevant outcome and addresses the paucity of studies on issues that remain major concerns for firms in Africa and other emerging continents (George et al., 2016).

The rest of the paper proceeds as follows. In the next sections, we introduce our theoretical framework, review related literature and develop the hypotheses. We also present the sources of data and describe our methodology. Thereafter, we report the results and discuss their implications for theory and practice. We conclude by outlining the limitations of the study and suggesting directions for further research.

\section{Theory and Hypotheses}

Organizational theorists have argued that managerial actions are embedded in networking relationships (Granovetter, 1973; Granovetter, 1985). These relationships create social 
capital, a valuable resource for firms. The central proposition of social capital theory suggests that networking relationships have a significant positive impact not only on individuals, but also on firms. In this respect, there are two main perspectives for examining the effect of social capital: the micro-micro link and micro-macro-link. While the micro-micro-link focuses on the impact of networking ties on managers and employees, the micro-macro link focuses on the effect of managerial ties on organizations (Gulati, 1995; Nahapiet and Ghoshal, 1998; Peng and Luo, 2000).

Building on the micro-macro link, management researchers have argued that the social capital of managers improves firm performance and reduces uncertainty by creating access to the polity and lessening information asymmetry (Peng and Luo, 2000; Acquaah, 2007). A popular argument in social capital studies suggests that networking relationships are more important and prevalent in emerging countries (Peng and Luo) where they serve as substitutes for weak market supporting institutions (Xin and Pearce, 1996).

Also important in emerging countries is institutional legitimacy (Ahlstrom, Bruton and Yeh, 2008). Legitimacy is gained when firms align their behaviours with their institutional environment (Suchman, 1995; Deephouse and Carter, 2005). Research shows that CSR improves legitimacy (Scherer, Palazzo and Seidl, 2013; Zheng et al., 2015; Hadani and Coombes, 2015; Beddewela and Fairbrass, 2016) which culminates in reduced risk exposure (Bansal and Roth, 2000; Luo, 2001; Stevens et al., 2016) and enhanced organizational performance (Mellahi et al., 2016). In Ghana and other emerging countries, CSR initiatives such as philanthropy are positively interpreted, hence firms that give back to society are widely respected, admired and tolerated (Ofori and Hinson, 2007). Moreover, CSR signals that a firm is well governed and well behaved in society (Hond et al., 2014). These positive views of CSR are expected to discourage public officials from subjecting responsible firms to administrative obstacles stemming from demands for informal payments, 
discrimination and bureaucratic red tape. Recent evidence that regulators are lenient with socially responsible firms (Hong and Liskovich, 2015) supports this claim. As the mechanisms of MPT and CSR are dissimilar, our study integrates social capital and institutional theories to explore institutional risk exposure in Ghana, an emerging African country.

Firms operating in emerging countries have a high exposure to uncertainty. Miller (1992) proposed five types of uncertainty. They include: 1) political uncertainty arising from regime changes; 2) government policy instability; 3) macroeconomic uncertainty; 4) social uncertainties; and 5) natural uncertainties. The first four types of uncertainty, together, underscore institutional risk. Government policies such as nationalization or expropriation; trade protection; earnings repatriation restrictions; import, export and currency restrictions; and capital controls have been established as common sources of risk. Risks increase economic and transaction costs (North, 1990; Williamson, 1991), endanger survival, reduce competitiveness, and consequently affect performance (Hillman and Hitt, 1999). Hence, it is imperative for firms to manage their exposure to risk by behaving responsibly (Doh et al., 2012; Shiu and Yang, 2015) or by developing ties to politicians (Hillman et al., 1999).

While the conceived efficacy of nonmarket strategies in risk reduction is common in the literature, empirical proof is lacking; there is a paucity of research on this very important topic. The study that is most related to ours was conducted by Puck and colleagues (2013) who did not find empirical evidence to support the proposition that political strategies reduce risk exposure. Building on Puck et al. (2013), our study extends the scope of nonmarket strategy by including the effects of CSR and PA functions to capture the multiplicity and heterogeneity as well as the interrelationship between political and social actors in business environments. Figure 1 shows our overall research model. 


\section{Managerial Political Ties and Institutional Risk}

Firms and governments exhibit a typical principal-agent relationship whereby the former are principals and the latter are agents (Getz, 1997). This relationship might be implicit and informal but as noted, not all principal-agent contracts are formalized (Jensen and Meckling, 1976). Governments are expected to act in the best interest of their constituents (including firms), but this does not always happen due to various reasons, such as politicians' lack of information about the consequences of policy (Lord, 1995). In emerging countries, firms face even greater institutional risks due to the volatility and fragility of the institutions in these countries (Luo, 2004). However, agency problems between firms and governments are manageable through political connections (Getz, 1997; Keim and Baysinger, 1993). For instance, Jayachandran (2006) argues that firms target their contributions towards politicians whose interests are aligned with theirs. This ensures that elected politicians invariably pursue the interests of supportive firms. Therefore, politically connected firms can get policy favours which help to reduce their risk exposure.

The ability of firms to use political connections to shape government policies or influence legislations (Liebman and Reynolds, 2006; Steagall and Jennings, 1996) empowers them to take control of their environments. Through political ties, firms get to know the intentions of policymakers (Hadani and Schuler, 2013). They gain access to information that is costly or difficult to obtain and are able to block the passage or implementation of detrimental policies (Doh et al., 2012). The consequent reduction of information asymmetry lessens the risks to which they are exposed. 
Moreover, the high propensity for governments to bail out politically connected firms (Blau, Brough, and Thomas, 2013; Faccio, Masulis, and McConnell, 2006) serves as an implicit guarantee of protection from shocks or voids in the environment. Politically connected firms may perform poorly but as they get support from the government, their probability of bankruptcy is low (Kostovetsky, 2015). Consequently, connected firms perceive a low exposure to risk due to receiving political protection. In emerging countries where the number or power of independent veto players (Henisz, 2004; Henisz and Delios, 2004) is typically low, the "rules of the game" are unclear, and legal frameworks are premature (Li, 2005; White et al., 2015), politicians can speed up slow bureaucratic processes and clear up major institutional obstacles that affect firms. We therefore hypothesize that:

H1: In an emerging country, managerial political ties reduce institutional risk exposure.

\section{Corporate Social Responsibility and Institutional Risk}

Firms can use CSR to influence their policy environments (Sun et al., 2012; Mellahi et al., 2016). Within the last decade, political CSR - which refers to CSR with intended or unintended political impact (Frynas and Stephens, 2015) - has received significant attention from management scholars (Palazzo and Scherer, 2011; Newell and Frynas, 2007). Beyond providing basic infrastructure for communities, filling development gaps in emerging countries and contributing to national and global regulation (Scherer and Palazzo, 2007; Margolis and Walsh, 2003), CSR increases reputation and enables firms to develop trustworthy relationships with community actors and politicians (Liedong et al., 2015). This resultant trust improves legitimacy (Hadani and Coombes, 2015), increases public goodwill, and reduces the exposure of firms to government intervention (Stevens et al., 2016) and other negative institutional effects (Luo, 2001; Henisz and Zelner, 2005) such as extortions, 
bribery, discrimination, or community revolts. We posit that positive public perceptions and legitimacy of socially responsible firms will cause public officials to exercise leniency in the application of regulations to these firms (Hong and Liskovich, 2015), speed up administrative processes and refrain from demanding bribes.

CSR is therefore expected to reduce risk, especially socially-driven risk. At worst, CSR will make managers feel insulated from institutional constraints due to the public goodwill associated with benevolent practices. In developing countries such as Ghana, public perceptions of firms are positively influenced by the level of support and moral obligations the firms have towards communities (Ofori and Hinson, 2007; Kuada and Hinson, 2012). At best, CSR will give managers the incentive to push institutional boundaries or the impetus to engage with relevant stakeholders to overcome institutional voids. Importantly, the chance of success in policy influence or risk reduction is higher for firms that are socially responsible (Hond et al., 2014; Liedong et al., 2015).

H2: In an emerging country, corporate social responsibility reduces institutional risk exposure.

\section{The Complementarity of Corporate Social Responsibility and Political Ties}

CSR can strengthen the effectiveness of political ties in reducing risk exposure. Mellahi et al. (2016) advocated that alignment between political connections and CSR activities enhances organizational performance. Similarly, Sun et al. (2012) argued that CSR may amplify the positive effects of political ties. With this in mind, Mellahi et al. (2016) further suggested that doing CSR in emerging countries does not only strengthen a firm's political connections and subsequently enhance its performance, but it may also serve as a buffer to the potentially risky effects of political connections. 
Insights from institutional legitimacy are particularly useful for articulating the complementarity of MPT and CSR. In emerging economies, a firm's engagement in CSR activities signals its health and indicates its willingness to address social problems. Recent research on the link between CSR and CPA suggests that doing CSR helps firms to gain political legitimacy, which increases their chances of getting government support (Lin et al. 2015). Legitimacy also increases the reputation and visibility of managers and helps them to further strengthen their social capital. Moreover, CSR complements MPT to develop strong trust which leads to effective policy influence. This is because MPTs alone are less trusted while CSR alone, through legitimacy, may create access to the polity but no influence (Liedong et al., 2015). However, when combined their synergy is greater. Furthermore, strong MPT may help firms legitimise and publicise their CSR activities (Mellahi et al., 2016). For example, having a high profile politician open a CSR initiative is likely to attract media coverage, thereby increasing firms' visibility and ratings by key stakeholders (Lawton, Doh, and Rajwani, 2014).

It is worth noting that there are few legal obligations for firms to do CSR in emerging countries (Hamann et al., 2005). CSR in these countries is largely a moral choice for most firms (Kuada and Hinson, 2012). Therefore, socially responsible firms are perceived to be trustworthy (Hillenbrand, Money, and Ghobadian, 2013; Pivato, Misani, and Tencati, 2008), have large and strong constituencies and are less likely to face resentment (Liedong et al., 2015). They are also more likely to be perceived as well governed due to their high visibility (Hond et al., 2014). The resultant institutional legitimacy and goodwill from CSR address the social roots of institutional risk. MPT may reduce political and policy uncertainties, but there could be instances when these uncertainties are initiated by the public or when corporate influence on policymaking is abhorred by society (Milyo, Primo, and Groseclose, 2000), especially in emerging countries where the dark side of political activity - corruption, 
bribery, cronyism, etc. - is more likely to manifest (Lawton, McGuire, and Rajwani, 2013a). Strong public resentment reduces politicians' discretion (Schuler, 2008) and renders MPT ineffective in institutional risk reduction. Therefore, we posit that combining CSR and MPT helps firms to develop trust and gain legitimacy with both political and social actors, expand their political capital and consequently reduce their risk exposure.

H3: In an emerging country, higher levels of social responsibility strengthen the ability of managerial political ties to reduce institutional risk exposure.

\section{The Moderating Effect of Public Affairs Function}

PAs offer channels for interaction between firms and their external environments (Griffin and Dunn, 2004). PA, a broader nonmarket function that supports, deepens and highlights CSR and CPA, focuses on the creation and maintenance of a specific set of external stakeholder relationships (Lawton et al., 2014). A PA serves as a window in and a window out of the firm (Adams, 1976). As a window in, it increases visibility, transparency and trust between a firm and its stakeholders, and thus improves institutional legitimacy. As a window out, it shapes the opinions of public stakeholders (i.e. government, public agencies) and private stakeholders (i.e. interest groups, non-governmental organizations). In this respect, PA functions can have a significant impact on the ability of MPT and CSR (separate or combined) to reduce risk exposure.

First, in emerging countries where institutions are still developing, the stakeholder environment is volatile and dynamic (Puck et al., 2013). Beside governments' substantial impact on the business climate of these countries (Child and Tse, 2001), private stakeholders such as non-governmental organizations (NGOs) also wield significant influence. For instance, on one hand, NGOs help to fill development gaps and protect human rights (Dahan, Doh, Oetzel and Yaziji, 2010), thus contributing to a better socio-economic environment 
within which firms can succeed. They may also serve as partners or collaborators for firms to overcome institutional constraints or implement adapted business models in developing markets (Boddewyn and Doh, 2011; Dahan et al., 2010; London and Hart, 2004; Oetzel and Doh, 2009). On the other hand, NGOs can instigate revolts and smear campaigns against firms (London and Hart, 2004), which can culminate in adverse policy actions and high exposure to institutional risk. The discussion above shows that private stakeholders have to be managed effectively in order to reduce risk in business environments, but they cannot be managed using political strategies. Rather, carefully planned PA programs which do not only keep private stakeholders informed but also offer opportunities for collaborative initiatives will best mitigate risks, create conducive business environments and confer external legitimacy on firms (Rondinelli and London, 2003). In other words, combining PA functions with MPT will ensure that public and private stakeholders are managed effectively to reduce risk exposure.

Second, PA functions increase the visibility of firms to external stakeholders. This increased visibility does not only confer legitimacy on the firms, but it also enhances the recognition and reputation of affiliated managers and employees. Drawing on the notion that organizational visibility increases employees' perceptions of self-worth (Fuller et al., 2006; Tyler, Degoey and Smith, 1996), we argue that managers will use the visibility, legitimacy and status of their firms to augment their self-esteem and boost their confidence to strengthen or expand their connections to the polity. PA-driven visibility and legitimacy will reinforce $\mathrm{CPA}$, lead to stronger political ties and eventually result in a lower exposure to risk.

Third, stakeholders are the providers of legitimacy (Chiu and Sharfman, 2011), but they cannot provide it if they are not aware or informed about the activities of firms. In essence, the ability of CSR to create corporate goodwill is lower when multiple stakeholders are unaware of firms' CSR initiatives. Visibility is therefore an important element in 
legitimacy creation, and it can be attained through PA functions. For instance, firms with high media coverage of their CSR programs experience greater scrutiny which helps to reduce information asymmetry between stakeholders and managers (Brammer and Millington, 2006), culminating in trust and legitimacy. Beside the role of PA functions in publicizing CSR for legitimacy-conferring outcomes such as risk reduction, the visibility derived from PA functions also heaps high expectations and pressure on firms (Meznar and Nigh, 2005) and makes them more socially responsive (Brammer and Millington, 2006; Chiu and Sharfman, 2011). With recent research demonstrating that NGOs have a considerable influence on corporate citizenship behaviour and CSR (Park and Ghauri, 2015), we contend that NGOs and other private stakeholders are drawn to firms that are highly visible through their PA activities. Consequently, PA functions will reinforce CSR to reduce institutional risk.

Strategically, firms with PA functions formalize their interaction with the external environment. Such formalization leads to strategic planning, evaluation or support for nonmarket strategies. We argue that PAs strengthen nonmarket strategies by serving as conduits for scanning and monitoring political and social movements in weak institutional contexts. This monitoring enables firms to develop and implement appropriate approaches for strengthening social capital, enhancing institutional legitimacy and reducing risk exposure. Indeed, when firms are properly designed or structured, they are more effective in managing external dependency (Kotter, 1979) and risk exposure (Dieleman and Boddewyn, 2012). In emerging countries however, the importance of PA functions is yet to be recognized as most firms, especially the locally owned firms, are not strategically organized to address external affairs.

In sum, the efficacy of nonmarket strategies is dependent on the formal organizational structures through which the strategies are implemented (Keim and Baysinger, 1988). In this 
respect, PA functions represent formalization and institutionalization of nonmarket strategy. These functions increase the scope of stakeholder management beyond CPA alone or CSR alone, reinforce both CPA and CSR, increase corporate visibility and confer legitimacy on firms. We therefore posit that the legitimizing role of PA functions will strengthen the main and interactive effects of MPT and CSR on institutional risk exposure.

H4a: In an emerging country, the presence of PA functions or departments in firms strengthens the ability of managerial political ties to reduce institutional risk exposure

H4b: In an emerging country, the presence of PA functions or departments in firms strengthens the ability of corporate social responsibility to reduce institutional risk exposure

H4c: In an emerging country, the interactive effect of political ties and social responsibility on institutional risk exposure is strengthened by the presence of PA functions or departments in firms

\section{Research Setting and Methodology}

This section presents the context of the study, the sources of data, techniques used to ensure reliability and validity of the findings, and a description of the variables and their measures.

\section{Research Setting}

There is inadequate strategy and management research on Africa (Hoskisson et al. 2000; Wright et al., 2005; Mellahi and Mol, 2015; Klingebiel and Stadler, 2015). Especially, there is a paucity of nonmarket strategy research on the continent. Emerging countries may share similar characteristics such as weak regulatory environments (Acquaah, 2007), but they may have unique institutional and social frameworks that differentiate them from one another. Consequently, it could be erroneous to generalize nonmarket strategy research findings from 
China, Malaysia, Indonesia, or Thailand to every other emerging country. The African continent has interesting phenomena that have not yet been examined, and thus presents opportunities for researchers to explore empirical blind spots and contribute to theory (Klingebiel and Stadler, 2015).

This study is set in Ghana in sub-Saharan Africa. Ghana is saddled with weak legal structures and pervasive corruption. Powers of the government are separated, but checks and balances are largely ineffective. Consequent of these institutional weaknesses, uncertainty is rife in the country. Institutional voids have not only worsened the country's macroeconomic fundamentals, but they have also harmed private sector development. For instance, pervasive corruption and economic mismanagement have been cited among the reasons why public debt stock soared from $\mathrm{GH} \phi 9.5$ billion to $\mathrm{GH} \not 97.2$ billion between 2008 and 2015, a figure representing $72.9 \%$ of GDP (Bank of Ghana, 2016). Also, unfavourable tax administration, bribery and corruption have discouraged entrepreneurs from participating in the formal sector (Koto, 2015). Precisely, informal firms dominate the private sector landscape in Ghana, employing $86.1 \%$ of the workforce in the country (Ghana Statistical Service, 2012). In light of the increased costs associated with institutional voids, formal entrepreneurship in Ghana has narrowly focused on high-rewarding industries such as mining, oil, energy and telecommunications. With a weak institutional environment, Ghana is a suitable context for examining the association between nonmarket strategy and institutional risk exposure.

\section{Sampling and Data}

In emerging countries, archival data is rare (Wright et al., 2005). In Ghana particularly, archival data is limited or unavailable (Acquaah, 2007; Amoako-Gyampah and Boye, 2001). This is because most firms in the country are privately owned and do not provide information 
to the public; only 37 firms were listed on the stock exchange at the time of this study. Hence we collected data using a survey, which we triangulated with secondary data where possible.

We designed a questionnaire which was shared with peers to check whether the items were appropriate for the constructs we wanted to examine (Fowler, 1995). The questionnaire was then pilot tested with 20 managers in Ghana to examine the validity of the questions visà-vis the Ghanaian environment (Mesquita and Lazzarini, 2008). As part of the pilot testing, face-to-face interviews were conducted with 10 managers to collect more information on content validity and appropriateness of the questions.

Following previous studies, we sought to maximize the response rate through assurances of anonymity (Acquaah, 2007), offers to share results upon completion (Chan, 2005) and endorsements (Hillman, 2003; Hillman and Wan, 2005). We obtained endorsements from the Ghana Investment Promotion Centre (GIPC) and the Association of Ghana Industries (AGI). These endorsees were strategically chosen to give credibility to the study, but not affect the results. GIPC, an agency under the Office of the President of Ghana, is responsible for promoting private sector development and attracting foreign investment into the country. Among its objectives is the creation of an enabling and supportive business environment devoid of institutional constraints. AGI is a business and pressure group made up of over 1200 small, medium and large scale firms operating in Ghana. AGI advocates for favourable business conditions for its members.

Data was collected from Chief Executive Officers (CEOs), Managing Directors (MDs) and other senior managers. The sample consisted of 300 firms selected from the membership directory of AGI, the online directory of BusinessGhana and GIPC's Ghana Club 100. Meeting the sampling requirement, all the selected firms operated in Ghana for at least three years. This requirement was used because the survey made reference to the past 
three years (2011 to 2013) as the time frame for responses, a strategy aimed at avoiding biased responses based on one-off positive or negative experiences (Mesquita and Lazzarini, 2008; White et al., 2015). Due to poor postal services in Ghana, the questionnaires and cover letters were delivered on-site. After several visits and phone calls, 188 surveys were collected from firms operating in 21 industries including mining, oil and gas, pharmaceuticals, telecommunications, and manufacturing. Nine surveys were unusable, leaving a final sample of 179 and a final response rate of $59.6 \%$.

\section{Validity and reliability}

We insisted that only senior managers completed the questionnaires. On the average, respondents worked at their respective companies for six-and-half years, suggesting that they are knowledgeable of their firms. We addressed common method variance (CMV) using various methods. First, we were careful with the wording of the questions. Because of the dark side of political connections (Doh et al., 2012), firms could be unwilling to disclose their political ties. Questions were therefore diligently phrased to reduce social desirability bias. Second, we reverse-phrased some of the questions in order to reduce acquiescence bias whereby respondents agree or disagree with statements regardless of content or without scrutiny (Winkler, Kanouse, and Ware, 1982). Reverse-phrasing works like a cognitive "speed ramp" which requires respondents to be more controlled in their cognitive processing (Hinkin, 1995). Third, we delivered two surveys, to be independently completed by two different managers, to each sampled firm (Lee and Miller, 1999) in order to control for single rater bias (Podsakoff et al., 2003). Surprisingly, only ten firms returned both questionnaires and inter-rater agreements were measured using Cohen's kappa (Cohen, 1960). The kappa statistic for all ten firms was statistically significant, and ranged from .818 to .944 , indicating that responding managers had a "very good" level of agreement (Altman, 1991). In general, the high level of agreement suggests that the remaining data from single respondents is 
reliable, as has been shown by other studies (Miller, Cardinal, and Glick, 1997; White et al., 2015). Even though it was difficult to obtain secondary data, we triangulated some of the primary data using information from secondary sources, and we were able to do this for the few publicly listed firms in the sample. Fourth, the inclusion of moderation effects in the analysis reduced the effect of CMV. According to methodologists, complex interactions are likely to be out of respondents' cognitive maps and are not predicted by CMV (Dooley and Fryxell, 1999). Because respondents are not able to guess the interactions that will be tested, they are not able to respond in a socially desirable manner. Finally, we performed the Harman's (1967) single factor test which did not indicate the existence of CMV.

We also tested for non-response bias using the approach of Armstrong and Overton (1977) whereby we compared early and late-arriving completed surveys. T-tests revealed no significant difference for any key items or variables, thus ruling out the existence of systemic non-response bias. Internal consistency was measured for all scales using Cronbach's alpha. A coefficient of 0.70 is typically considered adequate (Nunnally, 1978). All the scales have reliability scores above this threshold.

Following prior studies, we confirmed the factor structure of the constructs by performing confirmatory factor analysis (CFA). Additionally, CFA enabled us to derive other measures of reliability such as average variance extracted (AVE) and composite reliability (CR). As shown in Table 1, the AVE and CR scores exceed the minimum thresholds of 0.50 and 0.70 respectively (Fornell and Larcker, 1981). The high factor loadings support convergent validity (Hair et al., 1998). Also, the fit statistics $(\mathrm{CFI}=0.95, \mathrm{NFI}=0.96, \mathrm{IFI}=$ $0.98, \mathrm{RMSEA}=0.05, \mathrm{p}>0.05$ ) show that the measurement model fits the data well. We followed the approach of Ambos, Andersson and Birkinshaw (2010) and checked discriminant validity by comparing the square root of the AVE with the squared correlation between constructs. The AVE values are consistently larger than the correlations between the 
constructs, indicating that each construct has more internally extracted variance than the variance it shares with other constructs (Fornell and Larcker, 1981).

Insert Table 1 about here

\section{Variables and Measurement}

Independent variables: Following Peng and Luo (2000) and Guo et al. (2014), we developed a three-item scale to measure Managerial political ties $(\alpha=.94)$. This three-item scale measures the extent to which managers invest resources and time in establishing and maintaining relations with politicians. Respondents were asked to indicate their level of agreement with (a) investing in building ties with government officials (b) spending time dealing with government officials and (c) making efforts to ensure good relations with government officials. These were measured on a scale ranging from (1) "strongly disagree" to (7) "strongly agree". To measure $\operatorname{CSR}(\alpha=.80)$, we used the scale developed by Turker (2009). This scale comprehensively captures firms' CSR to society, employees, customers and government. Respondents were asked to indicate their level of agreement with the items on a scale ranging from (1) "strongly disagree" to (7) "strongly agree". Our exploratory and confirmatory factor analysis revealed three dimensions of CSR (see Table 1), which fit into a combined construct/variable. We measured PA function using a dummy, coded 1 and 0 for firms with and without PA departments or functions respectively.

Dependent variable: Drawing on previous studies (Puck et al., 2013; Schwens et al., 2011) and incorporating insights from The World Bank Enterprise Survey (WBES) and the International Country Risk Guide (ICRG) methodology, we developed an 11-item scale for measuring Institutional Risk Exposure $(\alpha=.75)$. We asked firms to indicate the extent to which certain political, economic and legal factors are obstacles to their operations, on a scale 
ranging from (1) "minor obstacle" to (7) "major obstacle". As expected, exploratory factor analysis revealed that institutional risk is a three-dimensional construct (see Table 1).

Confirmatory factor analysis confirmed the existence of a single construct for risk; hence the three dimensions were combined into an overall institutional risk exposure variable, as was done by Puck et al. (2013).

Control Variables: We controlled for other variables that can impact institutional risk exposure. Regulation has been noted as one of the strongest impetus for corporate political activity (Hansen and Mitchell, 2000; Mitchell, Hansen, and Jepsen, 1997). Firms in highly regulated industries have high stakes in government policy (Lang and Lockhart, 1990), and hence are actively involved in politics (Stigler, 1971). This high involvement in politics is expected to reduce risk exposure. Following Hadani and Schuler (2013), we also included regulation which is defined by a dummy, coded 1 for firms operating in highly regulated industries (telecommunications, pharmaceuticals and utilities, etc.). To test the presence of the liability of foreignness (Zaheer, 1995) with respect to institutional risk, we included Ownership which was defined by a dummy variable, coded 1 for foreign firms (more than $50 \%$ owned by foreign investors) and 0 for local firms. Older firms, through their acquisition of local knowledge and experience, can avoid risks. We therefore included and measured Age as the number of years the firm has been operational in Ghana. Institutional shareholders, by virtue of their large stakes, have a stronger motivation to help their firms overcome institutional constraints. To account for this, we included institutional ownership $(\alpha=.94)$. Respondents were asked to indicate the extent to which Pension Funds, Mutual Funds, Insurance companies, Charities, and Private Equity Firms hold shares in their companies, both as a proportion of total shareholding and on a Likert scale ranging from (1) "very low" to (7) "very high". As large firms have large exposures to the business environment, we 
controlled for firm size which is operationalized as the logarithm of the number of employees (Acquaah, 2007).

\section{Analysis and Results}

Multiple hierarchical regressions were run to test the hypotheses. Serial correlation was checked using the Durbin-Watson statistic (Durbin and Watson, 1951). We also checked whether any cases exerted undue influence over the parameters of the Models by analysing distances (Cook and Weisberg, 1982). We centred lower-order terms before creating the interaction terms (Aiken and West, 1991). There were no problems of multicollinearity (see VIFs in Table 2). To further check robustness, we ran the Models using bootstrapped samples which revealed that the coefficients are an accurate estimate.

Insert Table 2 about here

The means, standard deviations, VIFs and correlations between the variables are reported in Table 2. In Table 3, Model 1 shows the association between the control variables and institutional risk exposure. It reveals that institutional holding is negatively associated with institutional risk exposure while firm size and regulation are positively associated with risk exposure. This suggests that institutional holding reduces risk exposure whereas large and highly regulated firms are exposed to higher risk. In Models 2 and 4, the results show that CSR is negatively associated with institutional risk exposure (Model 2: $\beta=-0.08, p<$ 0.1; Model 4: $\beta=-0.10, p<0.1)$. This suggests that firms that are socially responsible perceive low risk exposure, hence providing support for $\mathrm{H} 2$. In Models 3 and 4, the results show that political ties are not significantly associated with risk exposure (Model 3: $\beta=0.05$, $p>0.1$; Model 4: $\beta=0.06, p>0.1$, even though the coefficients are positive. These results provide no support for $\mathrm{H} 1$. The moderating variable, PA, is significantly and negatively 
related to risk exposure (Model 5: $\beta=-0.47, p<0.01$ ), indicating the importance of the PA function for managing the external environment.

The moderating effect of CSR on the relationship between MPT and risk exposure is insignificant (Model 6: $\beta=0.04, p>0.1$ ) and thus warrants no further analysis. We therefore found no support for H3. In models 7 and 8, we followed the interpretation of interaction terms that have dummy variables as lower-order terms (Hardy, 1993) ${ }^{2}$. The interaction term MPT*PA (PA coding reversed) is significant (Model 7: $\beta=-0.18, p<0.01$ ) and the coefficient for MPT is also significant (Model 7: $\beta=0.10, p<0.05$ ), indicating that firms that are politically connected and have public affairs functions perceive high risk exposure. Hence we found no support for H4a. We also did not find evidence to support H4b. While CSR $*$ PA is significant (Model 8: $\beta=-0.23, p<0.05$ ), the co-efficient of CSR is insignificant (Model 8: $\beta=-0.03, p>0.1$ ). In Model 9, the three-way interaction between MPT, CSR and PA is insignificant and does not support H4c. In Model 10 however, this three-way interaction is significant, but CSR, MPT and MPT*CSR are insignificant, making the result uninterpretable.

Insert Table 3 about here

\section{Discussion and Conclusion}

Nonmarket strategy literature is replete with claims that political strategies and CSR reduce firms' exposure to risk (Baysinger, 1984; Hillman and Hitt, 1999). These claims are deeply rooted in conceptions that MPT replace inefficient and insufficiently developed market supporting institutions (Acquaah, 2007; Peng and Luo, 2000) and enable firms to obtain

\footnotetext{
${ }^{2}$ When a model contains an interaction term which is the product of a continuous variable and a dummy variable, coefficients on the lower-order continuous term are interpreted as the effect of the continuous variable only and only when the dummy variable is 0 . The results correspond with the group $=0$
} 
exclusive and first-hand information about policy (Pfeffer, 1972) or gain access to the corridors of regulatory power (Hillman, 2005). These claims are also based on evidence that CSR enables firms to gain institutional legitimacy (Beddewela and Fairbrass, 2016; Mellahi et al., 2016). Unfortunately, we did not find evidence to support the efficacy of MPT in institutional risk reduction or the complementarity between MPT and CSR. Essentially, the argument that political connections reduce uncertainty is unsupported. However, we found evidence to show that CSR reduces risk exposure, most probably through the goodwill and legitimacy creates.

This study makes important contributions to the literature. First, it contributes to the nonmarket literature by enhancing our understanding of the effect of MPT and CSR on risk exposure. It is worth mentioning that not much empirical work has been done on this topic. This study reveals that there is no significant association between political ties and risk exposure, and demonstrates that the conjectured ability of CPA to reduce risk might only be illusional, not real. It also highlights the role of PA functions in nonmarket strategy, and how visibility increases the risk exposure of politically connected firms (Puck et al., 2013). Though the findings do not support our hypotheses about the interactive effect of PA functions, the significant main effect of PA functions on risk exposure as well as the interactive effect of PA functions and MPT suggests the importance of these functions. In essence, this study shows that while institutional legitimacy leads to lower risk, it also places firms under scrutiny which adversely affects perceptions of risk exposure.

Second, this study is among early studies to empirically examine the complementarity between CPA and CSR, and hence fills the lack of insight into this interesting topic. CPA and CSR have been treated as silos which hardly interact (Mellahi et al., 2016), but recent work has posited that they can be integrated for high firm performance (Hond et al., 2014; Liedong et al., 2015). For instance, some scholars have suggested that CSR reduces barriers to 
political entry (Wang and Qian, 2011) and weakens the negative effect of CPA (Liedong et al., 2015; Sun et al., 2012). In spite of these positive arguments, we did not find evidence to support complementariness. The findings show that while CSR reduces perceptions of risk exposure, it is ineffective when combined with MPT, thereby suggesting the existence of "cannibalization" whereby MPT erode the gains of CSR. This study demonstrates that in institutionally voided environments such as Ghana, a proper alignment is required to realize the gains of CPA and CSR; otherwise value-erosion will occur (Hond et al., 2014).

In shedding more light on the contributions of our study, we draw greater attention to the fact that institutional risk in emerging countries is mostly policy oriented. We argue that political strategies with a strong focus on institutional entrepreneurship (Dacin, Goodstein, and Scott, 2002; DiMaggio, 1988) will be more effective for the creation of new institutions or the transformation of existing institutions, and hence will be more suitable to reduce institutional risk exposure. Such political strategies are informational in form and could include lobbying and petitioning. Unfortunately, lobbying and petitioning have limited scope and application in emerging countries where the structures for private sector participation in policymaking are lacking (Rajwani and Liedong, 2015). Rather, relational strategies such as MPT are predominant. Though political ties can facilitate access to the polity, they may not be effective for addressing institutional voids. In essence, political access is not the same as political influence (Kim, 2008; Liedong et al., 2015). We argue that more is required, beyond access, to instigate institutional entrepreneurship. MPT may not be useful for buffering against investment climate constraints because managers fail to further exploit their access to the polity.

Additionally, MPT are more likely to offer idiosyncratic benefits which cannot be assured or guaranteed in the future. As institutional voids become entrenched and political ties are ineffective for institutional entrepreneurship, firms may only use their ties to 
overcome or avoid institutional voids every time they are encountered, but the voids will remain and recur in the future. Consequently, all recurring voids will present new predicaments in which firms have chances of both success and failure. In effect, firms survive by the day. Such surviving-by-the-day mentality of managers could account for the insignificant association between MPT and institutional risk exposure. Moreover, political strategies are largely targeted at government officials and are therefore less effective for engaging with other stakeholders who can influence business environments. This argument may create the impression that combining MPT with CSR - which addresses non-political stakeholders - will significantly reduce risk exposure. Yet, the attempt to establish an integrated nonmarket strategy for risk reduction failed as no significant interaction between CSR and MPT was found. Hence an argument of complementarity cannot be supported. The singular significant effect of CSR on risk reduction did not bear on the interaction of MPT and CSR, highlighting a possible trade-off from combining CSR and CPA (Liedong et al., 2015). Put differently, when the results for CSR (negative and significant relationship with risk exposure), MPT (positive and insignificant relationship with risk exposure) and MPT*CSR (positive and insignificant relationship with risk exposure) are examined and interpreted together, they show that the significant effect of CSR is "cannibalized" by MPT when both are combined. Hence, instead of a complementary effect between CSR and MPT, the findings suggest a possible substitution effect. In this regard, the positive perceptions associated with CSR become tainted by the insecurity of political ties.

The MPT*PA result is very surprising, but explicable. PA functions increase the visibility of firms. Visibility can increase transparency and legitimacy and reduce risk exposure as this study shows, but it can also expose firms to the scrutiny of stakeholders and thus increases risk exposure (Meznar and Nigh, 1995; Puck et al., 2013). CPA has a dark side i.e. bribery, corruption, etc. (Doh et al., 2012; Lawton et al., 2013a), hence public perception 
of MPT is not always positive and most managers in emerging countries seem to know this. Once public resentment builds, politicians lose their discretion to favour firms (Schuler, 2008) and policy change becomes likely. Therefore, perceptions of risk exposure will increase when politically connected firms become visible to many stakeholders through their PA activities. In this respect, PA actions used to improve institutional legitimacy may eventually place firms' political activities under perusal. Moreover, the overwhelming power of politicians in emerging countries may lure managers into thinking that developing ties with politicians is the ultimate tactic. Such thinking could lead to less dedication towards PA activities which seem to be more effective in institutional risk reduction. On the flipside, the visibility PA activities give to CSR does not increase risk exposure. In fact, the direction of the CSR*PA result is negative, as expected, but only insignificant. Our findings therefore highlight the different effect of visibility on both CSR and MPT. Essentially, visibility of MPT has negative consequences for outcomes in weak institutional environments.

Besides theoretical contributions, this study has practical implications for managers. First, the findings challenge the efficacy of political ties in emerging countries, and suggest that managers who want to overcome the entrenched barriers and constraints in institutionally-voided countries should employ strategies that promote institutional entrepreneurship. In essence, political ties alone are not enough. Firms need to use informational strategies such as lobbying or petitioning as they are more effective for policy and regulatory influence (Rajwani and Liedong, 2015). Though the policy-making process in most emerging countries does not offer many opportunities for firms to be involved, firms must enhance their capabilities to comment on policy issues using petitions and press conferences. Second, CSR seems to have a much stronger effect on risk exposure; hence managers should implement CSR initiatives to improve legitimacy and gain the trust of institutional actors. In most emerging countries, CSR is a moral obligation (Kuada and 
Hinson, 2012), and is therefore highly appreciated. Third, for firms that do both CPA and CSR, there seems to be an eroding effect of the former on the latter. A careful alignment between CPA, CSR and PA is necessary to derive or preserve value from nonmarket strategy.

\section{Limitations and future Research}

Although this study presents findings that advance knowledge of nonmarket strategy, it is subject to some limitations. First, as typical with survey research, this study uses crosssectional data which makes the analyses susceptible to endogeneity. However, we followed previous studies and used a three-year framing for the responses in order to reduce the threat of reverse causality. In the analyses, the absence of autocorrelation of the residual errors also reduced the threat of endogeneity. However, endogeneity from other sources such as measurement errors and omitted variables could still affect the results. The findings must therefore be interpreted with caution. Second, this study focuses on a single political strategy

- MPT. It is possible that other strategies, such as campaign contributions and lobbying, will have different effects. Third, the results are context-specific. Though Ghana shares similar characteristics with other emerging countries, there are unique institutional and contextual elements across different emerging countries. As a result, caution is required when generalizing the findings and conclusions to other developing countries in or out of subSaharan Africa.

The afore-mentioned limitations, in addition to the counterintuitive results, open up interesting avenues for future research. First, it would be insightful for future studies to investigate the political strategy-institutional risk link using different political tactics and employing longitudinal or panel designs which rigorously address reverse causality and endogeneity. Additionally, future studies could focus on comparative analyses among emerging countries to make the findings generalizable. At the micro-level, future studies 
could explore how managers perceive institutional risk and how their perceptions trigger nonmarket strategic actions.

Second, the inclusion of PA has revealed interesting insights and we encourage future nonmarket strategy studies to further explore this function. Additionally, the way we measure PA leaves room for further investigation. A distinction must be made between having a PA function and performing PA functions. The efficacy of a PA, to a large extent, depends on its size and resource endowments (Lawton, Rajwani and Doh, 2013b). In reality, firms may have PAs in their structures, but the PAs may not be functional or effective. We therefore encourage future studies to measure PA using a scale and not a dummy. If objective data is available, it will be better to measure this variable using the number of PA employees or the budgetary allocations for PA functions.

Finally, the evidence herein does not support complementarity between CPA and CSR. As research on the combinative effects of CPA and CSR is increasing (Mellahi et al., 2016), this study calls on researchers to look beyond the positive effects of combining CPA and CSR. In this respect, future research should examine whether there is cannibalization or substitution, rather than complementarity, between the two activities. Does CSR or CPA erode the gains of the other? Does the alignment of CSR and CPA matter for realizing any gains from their combination? Are CPA and CSR complements or substitutes? These questions should be the focus of future research agenda. In sum, this study provides finegrained insights into the singular and combined effects of political and social strategies and thus enhances our understanding of integrated nonmarket strategy.

\section{References}

Acquaah, M. (2007). 'Managerial Social Capital, Strategic Orientation, and Organizational Performance in an Emerging Economy', Strategic Management Journal, 28, pp. 12351255 . 
Adams, J. S. (1976). 'The Structure and Dynamics of Behaviour in Organizational Boundary Roles.' In M. D. Dunnette (eds) Handbook of Industrial and Organizational Psychology, pp. 1175-1199. New York: Wiley.

Ahlstrom, D., G. D. Bruton and K. S. Yeh (2008). 'Private firms in China: Building legitimacy in an emerging economy', Journal of World Business, 43, pp. 385-399

Aiken, L. S. and S. G. West (1991). Multiple Regression: Testing and Interpreting Interactions. London: Newbury Park.

Altman, D. G. (1991). Practical Statistics for Medical Research. London: Chapman and Hall.

Ambos, T. C., U. Andersson and J. Birkinshaw (2010). 'What are the consequences of initiative-taking in multinational subsidiaries?', Journal of International Business Studies, 41, pp. 1099-1118

Amoako-Gyampah, K. and S. S. Boye (2001). 'Operations Strategy in an Emerging Economy: The Case of the Ghanaian Manufacturing Industry', Journal of Operations Management, 19, pp. 59-79.

Anaman, K. A. and F. Agyei-Sasu (2012). 'Impact of Democratic Political Transition on the Performance of Business Firms in Ghana', Economic Papers, 31, pp. 391-400.

Armstrong, J. S. and T. S. Overton (1977). 'Estimating Nonresponse Bias in Mail Surveys', Journal of Marketing Research, 14, pp. 396-402.

Bank of Ghana (2016), Summary of Economic and Financial Data, available at: https://www.bog.gov.gh/privatecontent/MPC_Press_Releases/Summary\%20of\%20Econ omic\%20and\%20Financial\%20data.pdf (accessed 21st June 2016).

Bansal, P. and K. Roth (2000). 'Why Companies Go Green: a Model of Ecological Responsiveness', Academy of Management Journal, 43, pp. 717-736.

Baysinger, B. D. (1984). 'Domain Maintenance as an Objective of Business Political Activity: An Expanded Typology', Academy of Management Review, 9, pp. 248-258.

Beddewela, E. and J. Fairbrass (2016). 'Seeking Legitimacy Through CSR: Institutional Pressures and Corporate Responses of Multinationals in Sri Lanka', Journal of Business Ethics, 136, pp. 503-522.

Blau, B. M., T. J. Brough, and D. W. Thomas (2013). 'Corporate Lobbying, Political Connections, and the Bailout of Banks', Journal of Banking \& Finance, 37, pp. 30073017.

Boddewyn, J. and J. Doh (2011). 'Global strategy and the collaboration of MNEs, NGOs, and governments for the provisioning of collective goods in emerging markets', Global Strategy Journal, 1, pp. 345-361.

Brammer, S. and A. Millington (2006). 'Firm size, organizational visibility and corporate philanthropy: an empirical analysis', Business Ethics: A European Review, 15, pp. 6-18. 
Chan, R. Y. K. (2005). 'Does the Natural-Resource-Based View of the Firm Apply in an Emerging Economy? A Survey of Foreign Invested Enterprises in China', Journal of Management Studies, 42, pp. 625-672.

Child, J. and D. K. Tse (2001). 'China's Transition and its Implications for International Business', Journal of International Business Studies, 32, pp. 5-21.

Cohen, J. (1960). 'A Coefficient of Agreement for Nominal Scales', Educational and Psychological Measurement, 20, pp. 37-46.

Cook, R. D. and S. Weisberg (1982). Residuals and Influence in Regression. New York: Chapman \& Hall.

Dacin, M. T., J. Goodstein, and W. R. Scott (2002). 'Institutional Theory and Institutional Change: Introduction to the Special Research Forum', Academy of Management Journal, 45, pp. 45-56.

Dahan, N. M., J. P. Doh, J. Oetzel and M. Yaziji (2010). 'Corporate-NGO Collaboration: Cocreating New Business Models for Developing Markets', Long Range Planning, 43, pp. 326-342.

Deephouse, D. L. and S. M. Carter (2005). 'An Examination of Differences Between Organizational Legitimacy and Organizational Reputation', Journal of Management Studies, 42, pp. 329-360.

Dieleman, M. and J. J. Boddewyn (2012). 'Using Organization Structure to Buffer Political Ties in Emerging Markets: A Case Study.' Organization Studies, 33, pp. 71-95.

Dieleman, M. and W. M. Sachs (2008). 'Coevolution of Institutions and Corporations in Emerging Economies: How the Salim Group Morphed into an Institution of Suharto's Crony Regime', Journal of Management Studies, 45, pp. 1274-1300.

DiMaggio, P. J. (1988). 'Interest and Agency in Institutional Theory.' In Institutional Patterns and Culture, edited by L. Zucker, 3-22. Cambridge, MA: Ballinger Publishing Company.

Doh, J. P., T. C. Lawton, and T. Rajwani (2012). 'Advancing Nonmarket Strategy Research: Institutional Perspectives in a Changing World.', Academy of Management Perspectives, 26, pp. 22-39.

Dooley, R. S. and G. E. Fryxell (1999). 'Attaining Decision Quality and Commitment from Dissent: the Moderating Effects of Loyalty and Competence in Strategic DecisionMaking Teams', Academy of Management Journal, 42, pp. 389-402

Durbin, J. and G. S. Watson (1951). 'Testing for Serial Correlation in Least Squares Regression', Biometrika, 38, pp. 159-178.

Faccio, M., R. W. Masulis, and J. J. McConnell. (2006). 'Political Connections and Corporate Bailouts', Journal of Finance, 61, pp. 2597-2635. 
Fornell, C. and D. F. Larcker (1981). 'Evaluating Structural Equation Models with Unobservable Variables and Measurement Error', Journal of Marketing Research, 18, pp. 39-50.

Fowler, F. J. (1995). Improving Survey Question: Design and Evaluation. Thousand Oaks, CA: Sage.

Frynas, J. G. and S. Stephens (2015). 'Political Corporate Social Responsibility: Reviewing Theories and Setting New Agendas', International Journal of Management Reviews, 17, pp. 483-509

George, G., C. Corbishley, J. N. O. Khayesi, M. R. Haas and L. Tihanyi (2016). 'Bringing Africa In: Promising Directions for Management Research', Academy of Management Journal, 59, pp. 377-393.

Getz, K. A. (1997). 'Research in Corporate Political Action', Business \& Society, 36, pp. 3272.

Ghana Statistical Service (2012), 2010 population and housing census, available at: http://www.statsghana.gov.gh/docfiles/2010phc/Census2010_Summary_report_of_final results.pdf (accessed 1st February 2016).

Granovetter, M. (1985). 'Economic Action and Social Structure: The Problem of Embededdness', American Journal of Sociology, 91, pp. 481-510.

Granovetter, M. (1973). 'The Strength of Weak Ties', American Journal of Sociology, 78, pp. 1360-1380.

Griffin, J. J. and P. Dunn (2004). 'Corporate Public Affairs: Commitment, Resources, and Structure', Business \& Society, 43, pp. 196-220.

Gulati, R. (1995). 'Social Structure and Alliance Formation: A Longitudinal Analysis', Administrative Science Quarterly, 40, pp. 619-652.

Guo, H., E. M. Xu, and M. Jacobs (2014). 'Managerial Political Ties and Firm Performance during Institutional Transitions: An Analysis of Mediating Mechanisms', Journal of Business Research, 67, pp. 116-127.

Hadani, M. and D. A. Schuler (2013). 'In Search of El Dorado: The Elusive Financial Returns on Corporate Political Investments', Strategic Management Journal, 34, pp. 165-181.

Hamann, R., T. Agbazue, P. Kapelus and A. Hein (2005). 'Universalizing Corporate Social Responsibility? South African Challenges to the International Organization for Standardization's New Social Responsibility Standard', Business and Society Review, 110, pp. 1-19.

Hansen, W. L. and N. J. Mitchell (2000). 'Disaggregating and Explaining Corporate Political Activity: Domestic and Foreign Corporations in National Politics', American Political Science Review, 94, pp. 891-903. 
Hardy, M. A. (1993). Regression with Dummy Variables (Quantitative Applications in the Social Sciences). Newbury Park, CA: Sage.

Harman, H. H. (1967). Modern Factor Analysis. Chicago, IL: University of Chicago Press.

Henisz, W. J. (2004). 'Political Institutions and Policy Volatility', Economics \& Politics, 16, pp. 1-27.

Henisz, W. J. and A. Delios (2004). 'Information Or Influence? The Benefits of Experience for Managing Political Uncertainty’, Strategic Organization, 2, pp. 389-421.

Henisz, W. J. and B. A. Zelner (2005). 'Legitimacy, Interest Group Pressures, and Change in Emergent Institutions: The Case of Foreign Investors and Host Country Governments', Academy of Management Review, 30, pp. 361-382.

Hillenbrand, C., K. Money, and A. Ghobadian (2013). 'Unpacking the Mechanism by which Corporate Responsibility Impacts Stakeholder Relationships', British Journal of Management, 24, pp. 127-146.

Hillman, A. J. (2005). 'Politicians on the Board of Directors: Do Connections Affect the Bottom Line?' Journal of Management, 31, pp. 464-481.

Hillman, A. J. (2003). 'Determinants of Political Strategies in US. Multinationals', Business \& Society, 42, pp. 455-484.

Hillman, A. J. and M. A. Hitt (1999). 'Corporate Political Strategy Formulation: A Model of Approach, Participation, and Strategy Decisions', Academy of Management Review, 24, pp. 825-842.

Hillman, A. J. and W. P. Wan (2005). 'The Determinants of MNE Subsidiaries' Political Strategies: Evidence of Institutional Duality', Journal of International Business Studies, 36, pp. 322-340.

Hillman, A. J., A. Zardkoohi, and L. Bierman (1999). 'Corporate Political Strategies and Firm Performance: Indications of Firm Specific Benefits from Personal Service in the US Government', Strategic Management Journal, 20, pp. 67-81.

Hinkin, T. R. (1995). 'A Review of Scale Development Practices in the Study of Organizations', Journal of Management, 21, pp. 967-988.

Hond, F., K. A. Rehbein, F. G. A. Bakker, and H. K. Lankveld (2014). 'Playing on Two Chessboards: Reputation Effects between Corporate Social Responsibility ( CSR) and Corporate Political Activity ( CPA)', Journal of Management Studies, 51, pp. 790-813.

Hong, H. G. and I. Liskovich (2015). 'Crime, Punishment and the Halo Effect of Corporate Social Responsibility', NBER Working Paper No. w21215.

Hoskisson, R. E., L. Eden, C. M. Lau, and M. Wright (2000). 'Strategy in Emerging Economies', Academy of Management Journal, 43, pp. 249-267. 
Jayachandran, S. (2006). 'The Jeffords Effect', Journal of Law and Economics, 49, pp. 397425.

Jensen, M. and W. H. Meckling (1976). 'Theory of the Firm: Managerial Behavior, Agency Costs and Ownership Structure', Journal of Financial Economics, 3, pp. 305-360.

Keim, G. D. and B. D. Baysinger (1993). 'The Efficacy of Business Political Activity: Competitive Considerations in a Principal-Agent Context.' In B. Mitnick (eds) Corporate Political Agency, pp. 152-170. Newbury Park, CA: Sage.

Keim, G. and B. Baysinger (1988). 'The Efficacy of Business Political Activity: Competitive Considerations in a Principal-Agent Context', Journal of Management, 14, pp. 163-180.

Khanna, T. and K. Palepu (1997). 'Why Focused Strategies may be wrong for Emerging Markets', Harvard Business Review, 75, pp. 41-51.

Khanna, T., K. G. Palepu, and J. Sinha (2005). 'Strategies that Fit Emerging Markets', Harvard Business Review, 83, pp. 63-76.

Kim, J. (2008). 'Corporate Lobbying Revisited', Business \& Politics, 10, pp. 1-23.

Kingsley, A. F., R. G. Vanden Bergh, and J. P. Bonardi (2012). 'Political Markets and Regulatory Uncertainty: Insights and Implications for Integrated Strategy', Academy of Management Perspectives, 26, pp. 52-67.

Klingebiel, R. and C. Stadler (2015). 'Opportunities and challenges for empirical research in Africa', Africa Journal of Management, 1, pp. 194-200.

Kostovetsky, L. (2015). 'Political Capital and Moral Hazard', Journal of Financial Economics, 116, pp. 144-159.

Koto, P. S. (2015). 'An Empirical Analysis of the Informal Sector in Ghana', Journal of Developing Areas, 49, pp. 93-108.

Kotter, J. P. (1979). 'Managing External Dependence.' Academy of Management Review, 4, pp. 87-92.

Kuada, J. and R. E. Hinson (2012). 'Corporate social responsibility (CSR) practices of foreign and local companies in Ghana', Thunderbird International Business Review, 54, pp. 521536.

Lacko, M. (2000). 'Hidden Economy - an Unknown Quantity? Comparative Analysis of Hidden Economies in Transition Countries, 1989-95', Economics of Transition, 8, pp. 117-149.

Lang, J. R. and D. E. Lockhart (1990). 'Increased Environmental Uncertainty and Changes in Board Linkage Patterns', Academy of Management Journal, 33, pp. 106-128.

Lashitew, A. A. (2014). 'The Effect of Political Connections on Credit Access: Does the Level of Financial Development Matter?' Kyklos, 67, pp. 227-254. 
Lawton, T. C., J. P. Doh, and T. Rajwani (2014). Aligning for Advantage. Oxford, England: Oxford University Press.

Lawton, T., S. McGuire, and T. Rajwani (2013a). 'Corporate Political Activity: A Literature Review and Research Agenda', International Journal of Management Reviews, 15, pp. 86-105.

Lawton, T., T. Rajwani, and J. Doh (2013b). 'The Antecedents of Political Capabilities: A Study of Ownership, Cross-Border Activity and Organization at Legacy Airlines in a Deregulatory Context', International Business Review, 22, pp. 228-242.

Lee, J. and D. Miller (1999). 'People Matter: Commitment to Employees, Strategy and Performance in Korean Firms', Strategic Management Journal, 20, pp. 579-593.

Li, H., L. Meng, Q. Wang, and L. Zhou (2008). 'Political Connections, Financing and Firm Performance: Evidence from Chinese Private Firms', Journal of Development Economics, 87, pp. 283-299.

Li, H. and Y. Zhang (2007). 'The role of managers' political networking and functional experience in new venture performance: Evidence from China's transition economy', Strategic Management Journal, 28, pp. 791-804.

Li, S. (2005). 'Why a Poor Governance Environment does Not Deter Foreign Direct Investment: The Case of China and its Implications for Investment Protection', Business Horizons, 48, pp. 297-302.

Lin, K. J., J. Tan, L. Zhao and K. Karim (2015). 'In the name of charity: Political connections and strategic corporate social responsibility in a transition economy', Journal of Corporate Finance, 32, pp. 327-346.

Liebman, B. H. and K. M. Reynolds (2006). 'The Returns from Rent Seeking: Campaign Contributions, Firm Subsidies and Byrd Amendment', Canadian Journal of Economics, 39, pp. 1345-1369.

Liedong, T. A., A. Ghobadian, T. Rajwani, and N. O'Regan (2015). 'Toward a View of Complementarity: Trust and Policy Influence Effects of Corporate Social Responsibility and Corporate Political Activity', Group \& Organization Management, 40, pp. 405-427.

London, T. and S. L. Hart (2004). 'Reinventing strategies for emerging markets: beyond the transnational model', Journal of International Business Studies, 35, pp. 350-370.

Lord, M. D. (1995). 'An Agency Theory Assessment of the Influence of Corporate Grassroots Political Activism', Academy of Management Best Papers Proceedings, pp. 396-400.

Luo, Y. (2004). 'Building a Strong Foothold in an Emerging Market: A Link between Resource Commitment and Environment Conditions', Journal of Management Studies, 41, pp. 749-773. 
Luo, Y. (2001). 'Toward a Cooperative View of MNC-Host Government Relations: Building Blocks and Performance Implications', Journal of International Business Studies, 32, pp. 401-420.

Margolis, J. D. and J. P Walsh (2003). 'Misery loves companies: Rethinking social initiatives by business', Administrative Science Quarterly, 48, pp. 268-305.

McWilliams, A. and D. Siegel (2001). 'Corporate Social Responsibility: a Theory of the Firm Perspective', Academy of Management Review, 26, pp. 117-127.

McWilliams, A., D. Siegel and P. M. Wright (2006). 'Corporate Social Responsibility: Strategic Implications', Journal of Management Studies, 43, pp. 1-18.

Mellahi, K., Frynas, J. G., Sun, P., and Siegel, D. (2016) A Review of the nonmarket strategy literature: toward a multi-theoretical integration. Journal of Management, 42, pp.143173.

Mellahi, K. and M. J. Mol (2015). 'Africa is just like every other place, in that it is unlike any other place', Africa Journal of Management, 1, pp. 201-209.

Mesquita, L. F. and S. G. Lazzarini (2008). 'Horizontal and Vertical Relationships in Developing Economies: Implications for SMEs' Access to Global Markets', Academy of Management Journal, 51, pp. 359-380.

Meznar, M. B. and D. Nigh (1995). 'Buffer or Bridge? Environmental and Organizational Determinants of Public Affairs Activities in American Firms', Academy of Management Journal, 38, pp. 975-996.

Miller, C. C., L. B. Cardinal, and W. H. Glick (1997). 'Retrospective Reports in Organizational Research: A Re-examination of Recent Evidence', Academy of Management Journal, 40, pp. 189-204.

Miller, K. D. (1992). 'A Framework for Integrated Risk Management in International Business', Journal of International Business Studies, 23, pp. 311-331.

Milyo, J., D. Primo, and T. Groseclose (2000). 'Corporate PAC Campaign Contributions in Perspective', Business \& Politics, 2, pp. 75-88.

Mitchell, N. J., W. L. Hansen, and E. M. Jepsen (1997). 'The Determinants of Domestic and Foreign Corporate Political Activity', The Journal of Politics, 59, pp. 1096-1113.

Nahapiet, J. and S. Ghoshal (1998). 'Social Capital, Intellectual Capital, and the Organizational Advantage’, Academy of Management Review, 23, pp. 242-266.

Nell, P. C., J. Puck and S. Heidenreich (2015). 'Strictly limited choice or agency? Institutional duality, legitimacy, and subsidiaries' political strategies', Journal of World Business, 50, pp. 302-311.

Newell, P. and J.G. Frynas (2007). 'Beyond CSR? Business, poverty and social justice', Third World Quarterly, 28, pp. 669-681. 
North, D. C. (1990). Institutions, Institutional Change and Economic Performance. Cambridge: Cambridge University Press.

Nunnally, J. C. (1978). Psychometric Theory. New York: McGraw-Hill.

Oetzel, J. and J. P. Doh (2009). 'MNEs and development: a review and reconceptualization', Journal of World Business, 44, pp. 108-120.

Ofori, D. F. and R. E. Hinson (2007). 'Corporate social responsibility (CSR) perspectives of leading firms in Ghana', Corporate Governance, 7, pp. 178-193.

Oliver, C. and I. Holzinger (2008). 'The Effectiveness of Strategic Political Management: A Dynamic Capabilities Framework', Academy of Management Review, 33, pp. 496-520.

Park, B. and P. N. Ghauri (2015). 'Determinants influencing CSR practices in small and medium sized MNE subsidiaries: A stakeholder perspective', Journal of World Business, 50, pp. 192-204.

Park, J., H. Lee and C. Kim (2014). 'Corporate social responsibilities, consumer trust and corporate reputation: South Korean consumers' perspectives', Journal of Business Research, 67, pp. 295-302.

Peng, M. W. and Y. Luo (2000). 'Managerial Ties and Firm Performance in a Transition Economy: The Nature of a Micro-Macro Link', Academy of Management Journal, 43, pp. 486-501.

Peng, M. W. and Peggy S. H. (1996). 'The Growth of the Firm in Planned Economies in Transition: Institutions, Organizations, and Strategic Choice', Academy of Management Review, 21, pp. 492-528.

Pfeffer, J. (1972). 'Size and Composition of Corporate Boards of Directors: The Organization and its Environment', Administrative Science Quarterly, 17, pp. 218-228.

Pivato, S., N. Misani, and A. Tencati (2008). 'The Impact of Corporate Social Responsibility on Consumer Trust: The Case of Organic Food', Business Ethics: A European Review, 17, pp. 3-12.

Podsakoff, P. M., S. B. MacKenzie, L. Jeong-Yeon, and N. P. Podsakoff (2003). 'Common Method Biases in Behavioral Research: A Critical Review of the Literature and Recommended Remedies', Journal of Applied Psychology, 88, pp. 879-903.

Puck, J. F., H. Rogers, and A. T. Mohr (2013). 'Flying Under the Radar: Foreign Firm Visibility and the Efficacy of Political Strategies in Emerging Economies', International Business Review, 22, pp. 1021-1033.

Rajwani, T. and T. A. Liedong (2015). 'Political Activity and Firm Performance within Nonmarket Research: A Review and International Comparative Assessment', Journal of World Business, 50, pp. 273-283. 
Rasche, A. (2012). 'Global Policies and Local Practice: Loose and Tight Couplings in MultiStakeholder Initiatives', Business Ethics Quarterly, 22, pp. 679-708.

Rehbein, K. and D. A. Schuler (2015). 'Linking Corporate Community Programs and Political Strategies', Business \& Society, 54, pp. 794-821.

Rondinelli, D. A. and T. London (2003). 'How corporations and environmental groups cooperate: Assessing cross-sector alliances and collaborations', Academy of Management Executive, 17, pp. 61-76.

Scherer, A. G., D. Baumann-Pauly and A. Schneider (2013). 'Democratizing Corporate Governance: Compensating for the Democratic Deficit of Corporate Political Activity and Corporate Citizenship', Business \& Society, 52, pp. 473-514.

Scherer, A. G. and G. Palazzo (2007). 'Toward a political conception of corporate responsibility: Business and society seen from a habermasian perspective', Academy of Management Review, 32, pp. 1096-1120.

Scherer, A. G. and G. Palazzo (2011). 'The New Political Role of Business in a Globalized World: A Review of a New Perspective on CSR and its Implications for the Firm, Governance, and Democracy', Journal of Management Studies, 48, pp. 899-931.

Schuler, D. A. (2008). 'Peering in from corporate political activity', Journal of Management Inquiry, 17, pp. 162-167.

Schwens, C., J. Eiche, and R. Kabst (2011). 'The Moderating Impact of Informal Institutional Distance and Formal Institutional Risk on SME Entry Mode Choice', Journal of Management Studies, 48, pp. 330-351.

Shiu, Y. and S. Yang (2015). 'Does Engagement in Corporate Social Responsibility Provide Strategic Insurance-like Effects?', Strategic Management Journal, In press, DOI: $10.1002 / \mathrm{smj} .2494$.

Steagall, J. W. and K. Jennings (1996). 'Unions, PAC Contributions, and the NAFTA Vote', Journal of Labor Research, 17, pp. 515-521.

Stevens, C. E., E. Xie and M. W. Peng (2016). 'Toward a legitimacy-based view of political risk: The case of Google and Yahoo in China', Strategic Management Journal, 37, pp. 945-963.

Stigler, G. (1971). 'The Theory of Economic Regulation', Bell Journal of Economics and Management Science, 2, pp. 3-21.

Suchman, M. C. (1995). 'Managing Legitimacy: Strategic and Institutional Approaches', Academy of Management Review, 20, pp. 571-610.

Sun, P., K. Mellahi, and M. Wright (2012). 'The Contingent Value of Corporate Political Ties', Academy of Management Perspectives, 26, pp. 68-82. 
Torgler, B. and F. Schneider (2009). 'The Impact of Tax Morale and Institutional Quality on the Shadow Economy', Journal of Economic Psychology, 30, pp. 228-245.

Turker, D. (2009). 'Measuring Corporate Social Responsibility: A Scale Development Study', Journal of Business Ethics, 85, pp. 411-427.

Wang, H. and C. Qian (2011). 'Corporate philanthropy and corporate financial performance: the roles of stakeholder response and political access', Academy of Management Journal, 54, pp. 1159-1181.

Werner, T (2015). 'Gaining access by doing good: The effect of socio-political reputation on firm participation in public policymaking', Management Science, 61, pp 1989-2011.

White, G. O., J. J. Boddewyn, and R. M. N. Galang (2015). 'Legal System Contingencies as Determinants of Political Tie Intensity by Wholly Owned Foreign Subsidiaries: Insights from the Philippines', Journal of World Business, 50, pp. 342-356.

Williamson, O. E. (1991). 'Comparative Economic Organization: The Analysis of Discrete Structural Alternatives', Administrative Science Quarterly, 36, pp. 269-296.

Williamson, O. E. (2000). 'The New Institutional Economics: Taking Stock, Looking Ahead', Journal of Economic Literature, 38, pp. 595-613.

Winkler, J. D., D. E. Kanouse, and J. E. Ware (1982). 'Controlling for Acquiescence Response Set in Scale Development', Journal of Applied Psychology, 67, pp. 555-561.

Wright, M., I. Filatotchev, R. E. Hoskisson, and M. W. Peng (2005). 'Strategy Research in Emerging Economies: Challenging the Conventional Wisdom', Journal of Management Studies, 42, pp. 1-33.

Xin, K. K. and J. L. Pearce (1996). 'Guanxi: Connections as Substitutes for Formal Institutional Support', Academy of Management Journal, 39, pp. 1641-1658.

Zaheer, S. (1995). 'Overcoming the Liability of Foreignness', Academy of Management Journal, 38, pp. 341-36

Zheng, Q., Y. Luo and V. Maksimov (2015). 'Achieving legitimacy through corporate social responsibility: The case of emerging economy firms', Journal of World Business, 50, pp. 389-403. 


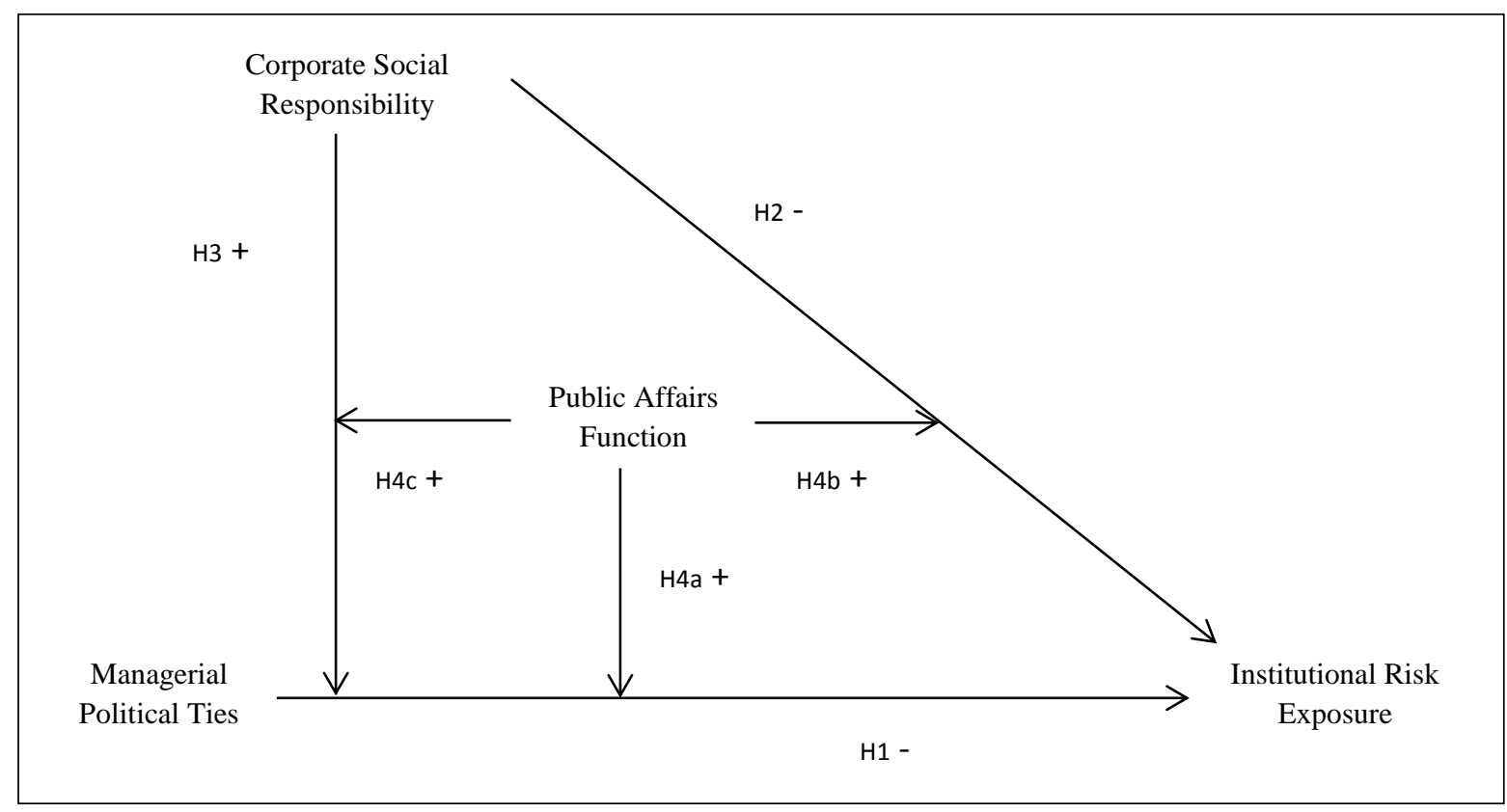

Figure 1: Research Model 
Table 1: Constructs, Measurement Items, Reliability and Validity

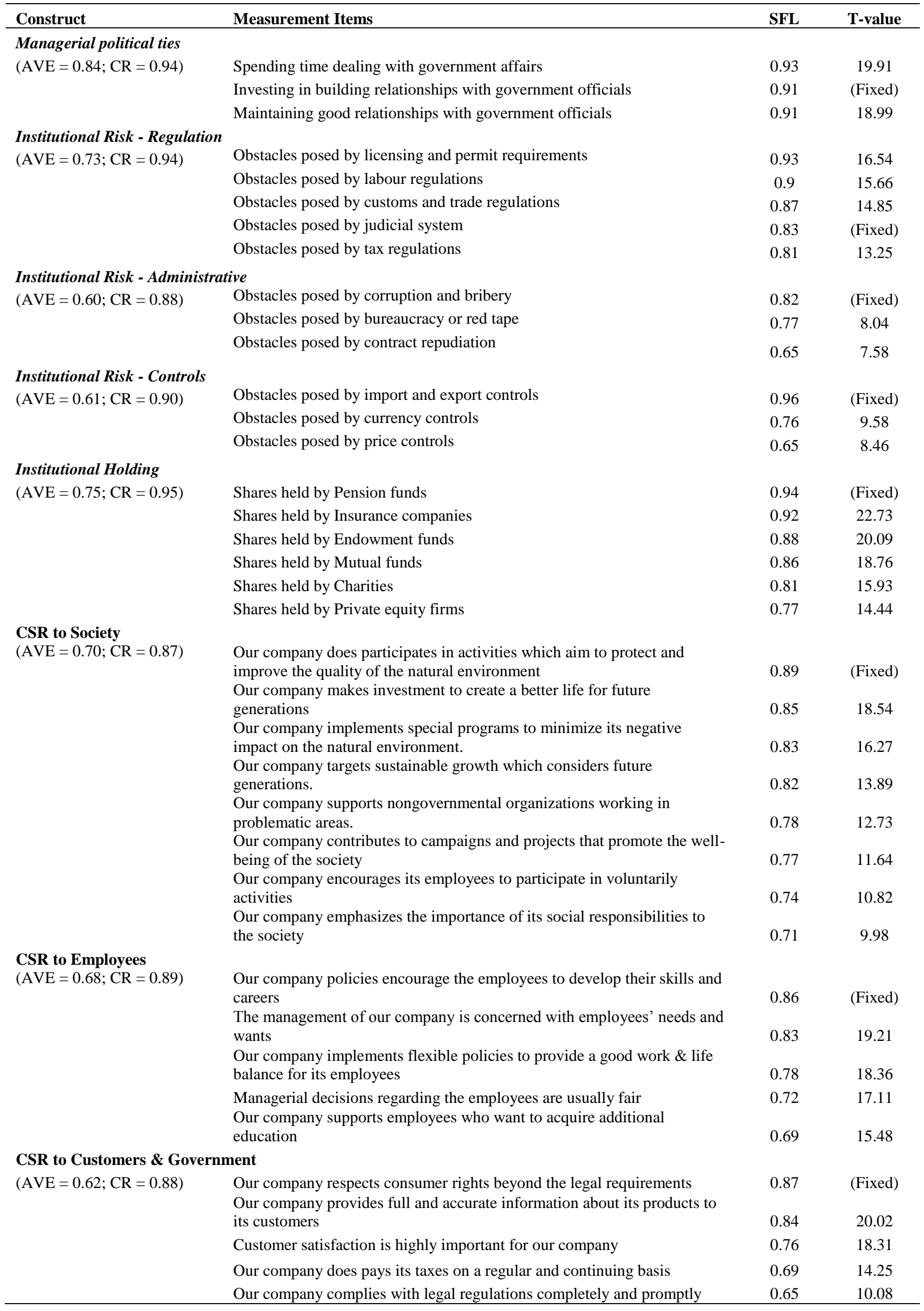


Table 2: Descriptives and Correlations

\begin{tabular}{|c|c|c|c|c|c|c|c|c|c|c|c|c|c|}
\hline & & Mean & SD & 1 & 2 & 3 & 4 & 5 & 6 & 7 & 8 & 9 & $\begin{array}{c}\text { Highest } \\
\text { VIF }\end{array}$ \\
\hline 1 & Institutional Risk & 2.92 & 0.97 & - & & & & & & & & & \\
\hline 2 & $\begin{array}{l}\text { Managerial Political } \\
\text { Ties }\end{array}$ & 3.90 & 2.19 & $0.16^{* *}$ & - & & & & & & & & 1.27 \\
\hline 3 & Social Responsibility & 4.99 & 1.37 & 0.03 & $0.19 * *$ & - & & & & & & & 1.29 \\
\hline 4 & Public Affairs & 0.62 & 0.49 & $-0.19 * *$ & -0.09 & -0.11 & - & & & & & & 1.32 \\
\hline 5 & Regulation & 0.42 & 0.49 & $0.23 * * *$ & 0.09 & 0.12 & 0.08 & - & & & & & 1.07 \\
\hline 6 & Institutional Holding & 2.08 & 1.51 & $-0.19 * * *$ & 0.06 & $-0.23 * * *$ & $0.28 * * *$ & -0.07 & - & & & & 1.21 \\
\hline 7 & Firm Age & 19.17 & 17.1 & 0.06 & $0.36^{* * *}$ & 0.01 & $0.26^{* * *}$ & -0.05 & $0.27 * * *$ & - & & & 1.40 \\
\hline 8 & Firm Size & 4.56 & 0.91 & $0.14 *$ & $0.12^{*}$ & 0.10 & $0.33^{* * *}$ & 0.06 & 0.11 & $0.26^{* * *}$ & - & & 1.20 \\
\hline 9 & Ownership & 0.45 & 0.50 & -0.11 & -0.05 & $-0.37 * * *$ & $0.15^{* *}$ & $-0.17 * *$ & $0.13^{*}$ & $0.19 * *$ & 0.03 & - & 1.25 \\
\hline
\end{tabular}

$* * * p<0.01 ; * * p<0.05 ; * p<0.1$ (Two-tailed significance tests) 
Reality or Illusion? The Efficacy of Nonmarket Strategy in Institutional Risk Reduction

Table 3: Regression Results

\begin{tabular}{|c|c|c|c|c|c|c|c|c|c|c|}
\hline \multirow[t]{2}{*}{ Variables } & \multicolumn{10}{|c|}{ Institutional Risk Exposure } \\
\hline & Model 1 & Model 2 & Model 3 & Model 4 & Model 5 & Model 6 & Model 7 & Model 8 & Model 9 & Model 10 \\
\hline \multicolumn{11}{|l|}{ Control Variables } \\
\hline Institutional Holding & $-0.14 * * *$ & $-0.16^{* *}$ & $-0.14 * * *$ & $-0.16^{* * *}$ & $-0.13^{* *}$ & $-0.13 * * *$ & $-0.13 * * *$ & $-0.13 * *$ & $-0.12 * *$ & $-0.13 * * *$ \\
\hline Firm Age & 0.01 & 0.01 & 0.00 & 0.00 & 0.01 & $0.01 * *$ & 0.01 & 0.01 & 0.01 & $0.01 * *$ \\
\hline Firm Size & $0.13^{*}$ & 0.15 & 0.13 & $0.15 *$ & $0.22 * * *$ & $0.22 * * *$ & $0.20 * *$ & $0.22 * * *$ & $0.20 * *$ & $0.17 * *$ \\
\hline Ownership & -0.15 & -0.24 & -0.13 & -0.22 & -0.19 & -0.17 & -0.16 & -0.26 & -0.19 & -0.19 \\
\hline Regulation & $0.41 * * *$ & $0.42 * * *$ & $0.39 * * *$ & $0.40 * * *$ & $0.46 * * *$ & $0.48 * * *$ & $0.43^{* * *}$ & $0.44 * * *$ & $0.43 * * *$ & $0.37 * * *$ \\
\hline \multicolumn{11}{|l|}{ Predictor Variables } \\
\hline Social Responsibility (CSR) & & $-0.08^{*}$ & & $-0.10 *$ & $-0.11 *$ & -0.06 & -0.08 & -0.03 & $-0.11 *$ & 0.15 \\
\hline Managerial Political Ties (MPT) & & & 0.05 & 0.06 & 0.04 & 0.01 & $0.10 * *$ & 0.05 & 0.04 & 0.06 \\
\hline \multicolumn{11}{|l|}{ Contingency Variable } \\
\hline Public Affairs (PA) & & & & & $-0.49 * * *$ & $-0.47 * * *$ & $-0.48 * * *$ & $-0.47 * * *$ & $-0.51 * * *$ & $-0.52 * * *$ \\
\hline \multicolumn{11}{|l|}{ Interactions } \\
\hline $\mathrm{MPT}^{*} \mathrm{CSR}$ & & & & & & 0.04 & & & & 0.12 \\
\hline MPT*PA & & & & & & & $-0.18 * * *$ & & & -0.11 \\
\hline CSR $* \mathrm{PA}$ & & & & & & & & $-0.23 * * *$ & & $-0.34 * * *$ \\
\hline $\mathrm{MPT} * \mathrm{CSR} * \mathrm{PA}$ & & & & & & & & & -0.04 & $-0.15 * * *$ \\
\hline \multicolumn{11}{|l|}{ Model Stats } \\
\hline Adjusted R2 & 0.1 & 0.11 & 0.10 & 0.12 & 0.16 & 0.16 & 0.19 & 0.17 & 0.16 & 0.24 \\
\hline Model F & $4.89 * * *$ & $4.86^{* * *}$ & $4.44 * * *$ & $4.28 * * *$ & $5.10 * * *$ & $4.80 * * *$ & $5.53 * * *$ & $5.11 * * *$ & $4.61 * * *$ & $5.68 * * *$ \\
\hline
\end{tabular}

$\mathrm{N}=179 . * * * \mathrm{p}<0.01 ; * * \mathrm{p}<0.05 ; * \mathrm{p}<0.1$ (two-tailed significance tests) 